\title{
IMPLEMENTASI KEBIJAKAN PENINGKATAN KOMPETENSI PENDIDIK MELALUI PENINGKATAN RASIO PENDIDIK \& PEMERATAAN PENYEBARAN PENDIDIK DI KABUPATEN JENEPONTO \\ Nuryanti Mustari
}

Fakultas Ilmu Sosial dan Ilmu Politik Universitas Muhammadiyah Makassar

Jl. Sultan Alauddin No. 259 Makassar 90221

Telp. 0411 - 866972 ext. 107 Fax. 0411 - 865588

\section{ABSTRAK}

Penelitian ini bertujuan untuk mengetahui: Implementasi Kebijakan Peningkatan rasio pendidik dan pemerataan penyebaran pendidik di Kabupaten Jeneponto sebagai salah satu program untuk meningkatkan kompetensi pendidik yang muaranya adalah meningkatkan mutu pendidikan di Kabupaten Jeneponto. Sampel penelitian adalah implementor kebijakan yaitu Dinas Pendidikan, Pemuda dan Olahraga Kabupaten Jeneponto dan Objek Kebijakan yaitu guru-guru IPA, IPS dan Bahasa SMA se Kabupaten Jeneponto yaitu 7 Sekolah Menengah Atas. Dan Informan dari institusi Dinas Pendidikan yaitu Kepala Dinas pendidikan, Sekretaris Dinas pendidikan, Kepala Bidang Ketenagaan, dan Kepala Bidang Kejuruan dan SLTA. Responden dipilih melalui teknik Proportional Random Sampling. Pengumpulan data dilakukan dengan menggunakan kuesioner, dokumentasi, rekaman arsip, wawancara dan observasi langsung. Teknik analisas data adalah teknik analisa siklus yang meliputi tahap-tahap reduksi data, penyajian data dan penarikan kesimpulan.

Hasil Penelitian menunjukkan bahwa implementasi kebijakan peningkatan rasio pendidik dan pemerataan penyebaran pendidik di Kabupaten Jeneponto belum berjalan efektif sehingga masih banyak yang perlu dibenahi dan diperhatikan oleh Pemerintah.

Kata Kunci : Implementasi Kebijakan Peningkatan peningkatan rasio pendidik dan pemerataan penyebaran pendidik.

\section{A. PENDAHULUAN}

Isu sentral yang berkembang di Indonesia dewasa ini dalam bidang pendidikan adalah masalah rendahnya mutu pendidikan. Kualitas pendidikan di Indonesia dinilai masih rendah bila dibandingkan dengan negara lain. Hal ini dibuktikan dari fakta dalam beberapa tahun terakhir tentang mutu pendidikan di Indonesia yang sungguh memprihatinkan. Menurut Engkoswara dalam seminar Nasional
Kualitas Pendidikan dalam membangun kualitas bangsa (Desember, 2006) bahwa Indonesia hanya menempati urutan 102 dari 107 negara di dunia dan urutan 41 dari 47 negara di Asia.

Fakta lain bahwa kualitas pendidikan kita masih rendah, tertinggal dibanding negara lain dilihat dari Laporan United National, Scientific, and Cultural Organisation (UNESCO), 
November 2007 menyebutkan peringkat Indonesia di bidang pendidikan turun dari peringkat 58 ke peringkat 62 . Selain itu, rendahnya mutu pendidikan Indonesia juga dapat dilihat dari rendahnya daya saing Indonesia, yang menurut World Economic Forum, 2007-2008 berada di level 54 dari 131 negara, jauh di bawah peringkat daya saing sesama Negara Asean seperti Malaysia yang berada di urutan ke-21 dan Singapura berada pada urutan ke-7. Hal yang perlu diketahui bahwa kualitas sumber daya manusia menjadi salah satu faktor penyebab rendahnya daya saing selain faktor birokrasi, lingkungan serta perangkat dan penegakan hukum (Tangkilisan, 2008).

Rendahnya mutu pendidikan di Indonesia dapat juga dilihat dari rendannya standar kelulusan yang ditetapkan. Data Departemen Pendidikan Nasional menunjukkan bahwa pada tahun 2004/2005 standar kelulusan Ujian Akhir Nasional (UAN) adalah 4,01. Penetapan standard tersebut adalah tergolong rendah, jauh dari standar kelulusan Malaysia yang mematok angka 6,00, dan standard kelulusan Singapura yang mematok angka 8,00. Ironisnya, pada Tahun 2004 dengan standar kelulusan yang tergolong rendah tersebut, pada pelaksanaan Ujian Akhir Nasional (UAN) Tahun 2004, hasilnya sangat mengagetkan semua pihak karena masih saja ada sekolah yang jumlah siswanya tidak lulus 100\% (Depdiknas). Dunia pendidikan dalam hal ini Departemen Pendidikan Nasional (Depdiknas) menuai protes baik dari masyarakat maupun dari orang tua siswa. Siswa yang tidak lulus diberikan kesempatan untuk mengikuti ujian ulang. Hebatnya dengan tanpa diberikan program pengayaan dan remedial, hasil ujian tersebut nyaris tidak terdengar ada yang tidak lulus.

Pada Tahun 2005/2006 dilaksanakan Ujian Nasional (UN) yang merupakan penerapan kurikulum berbasis kompetensi (KBK) dengan standard kelulusan sedikit dinaikkan menjadi 4,25, tetapi juga hasilnya tidak jauh berbeda dengan UAN tahun 2004 yang juga menuai protes dari berbagai pihak termasuk pengamat pendidikan dan politisi di DPR yang menginginkan ditiadakannya
UAN (Marliana, 2007). Hal ini disebabkan karena nasib siswa SMA ditentukan oleh empat bidang studi yang diujikan, satu bidang studi saja yang tidak mencapai standar kelulusan walaupun ada bidang studi lain yang nilainya melebihi standar dan dapat menutupi kekurangan nilai dari bidang studi yang tidak mencapai standard tersebut, tetap saja siswa dinyatakan tidak lulus. Contoh kasus adalah juara olympiade Fisika yang gagal Ujian Nasional karena nilai Matematikanya hanya 4,00. Selain itu, banyak siswa SMA yang mengikuti penerimaan mahasiswa baru di perguruan tinggi negeri (PTN) melalui jalur penelusuran minat dan kemampuan (PMDK) yang diterima di salah satu PTN, tidak bisa melanjutkan pendidikannnya.

Rendahnya mutu pendidikan adalah persoalan bangsa yang sangat krusial, yang membutuhkan perhatian semua pihak khususnya pemerintah. Demikian pula yang terjadi di Kabupaten Jeneponto Propinsi Sulawesi Selatan.

Rendahnya mutu pendidikan di Kabupaten Jeneponto, kususnya pada tingkat SLTA dapat dilihat dari prosentase kelulusan dan niali ratarata Ujian Akhir Nasional yang merupakan tonggak-tonggak keberhasilan sekolah dalam upaya peningkatan mutu pendidikan, serta tingkat kelulusan pada perguruan tinggi negeri yang merupakan barometer untuk mengukur prestasi sekolah dalam memberikan pelayanan minimal pendidikan.

Tabel 1.

Persentase Kelulusan Peserta Ujian Nasional Tingkat SLTA Kabupaten Jeneponto 2006-2008

\begin{tabular}{|c|c|c|c|c|c|}
\hline Tahun & $\begin{array}{c}\text { Jumlah } \\
\text { Peserta }\end{array}$ & $\begin{array}{c}\text { Jumlah } \\
\text { Lulus }\end{array}$ & $\begin{array}{c}\text { Presentase } \\
\text { Lulus }\end{array}$ & $\begin{array}{c}\text { Presentase } \\
\text { Kelulusan Sulsel }\end{array}$ & $\begin{array}{c}\text { Peringkat } \\
\text { Se Sulsel }\end{array}$ \\
\hline 2006 & 1503 & 1499 & $99,73 \%$ & $96,80 \%$ & 3 \\
\hline 2007 & 1493 & 1472 & $98,59 \%$ & $94,37 \%$ & 4 \\
\hline 2008 & 1497 & 1468 & $98,06 \%$ & $96,74 \%$ & 9 \\
\hline
\end{tabular}

Sumber Data Sekunder Dinas Pendidikan Provinsi Sulsel, 2009

Informasi yang dapat kita telah adalah bahwa persentase kelulusan siswa Sekolah Menengah Tingkat Atas Kabupaten Jeneponto mengalami penurunan, kurun waktu 20062008, sementara disisi lain juga memperlihatkan persentase kelulusan yang lebih tinggi dari persentase rata-rata kelulusan Sekolah Menengah Atas (SMA) se-Sulawesi 
Selatan.

Persentase kelululusan siswa Sekolah Menengah Atas Kabupaten Jeneponto walaupun mengalami penurunan yang cukup signifikan kurun waktu 2006-2008, tetapi memperlihatkan prosentase rata-rata kelulusan yang jauh diatas prosentase rata-rata kelulusan Sekolah Menengah Atas tingkat Sulawesi Selatan. Ironisnya, dengan prosentase kelulusan siswa Sekolah Menengah Atas Kabupaten Jeneponto yang tinggi ternyata berbanding terbalik dengan capaian Nilai Ujian Akhir Sekolah yang memperlihatkan penurunan yang signifikan kurun waktu 2006-2008, khususnya untuk jurusan IPA dan IPS. Padahal, capaian Nilai Ujian Akhir Nasional merupakan tonggak-tonggak keberhasilan sekolah dalam upaya peningkatan mutu pendidikan. Rendahnya atau menurunnya mutu pendidikan di Kabupaten Jeneponto dapat dilihat dari penurunan capaian nilai ujian akhir nasional. Untuk lebih jelasnya, akan diuraikan dalam Tabel 2 berikut:

Tabel 2.

Capaian Nilai Ujian Akhir Nasional Tingkat SLTA Kabupaten Jeneponto Tahun 2006-2008

\begin{tabular}{|c|c|c|c|c|c|c|c|c|c|}
\multirow{2}{*}{ Tahun } & \multicolumn{4}{|c|}{ Jurusan } & \multicolumn{3}{c|}{$\begin{array}{c}\text { Nilai Rata-Rata } \\
\text { UAN Tingkat Sulsel }\end{array}$} & \multicolumn{3}{c|}{$\begin{array}{c}\text { Perolehan } \\
\text { Peringkat Sulsel }\end{array}$} \\
\cline { 3 - 11 } & IPA & IPS & BHS & IPA & IPS & BHS & IPA & IPS & BHS \\
\hline 2006 & 25,00 & 22,88 & 24,29 & 23,77 & 22,55 & 22,68 & 2 & 7 & 2 \\
\hline 2007 & 22,95 & 21,31 & 22,25 & 23,51 & 21,71 & 21,10 & 16 & 11 & 6 \\
\hline 2008 & 46,81 & 45,42 & 46,79 & 46,77 & 46,26 & 42,60 & 15 & 20 & 1 \\
\hline
\end{tabular}

Sumber Data Sekunder Dinas Pendidikan Provinsi Sulsel, 2009

Rendahnya mutu pendidikan di Kabupaten Jeneponto khususnya pada tingkat SLTA, dapat pula dilihat dari rendahnya tingkat kelulusan siswa dalam seleksi Ujian Masuk Perguruan Tinggi Negeri yang merupakan barometer untuk mengukur prestasi sekolah dalam memberikan pelayanan minimal pendidikan. Pada Tahun 2006, dari 1499 jumlah lulusan Sekolah Menegah Atas, sekitar 824 siswa tersebar pada perguruan tinggi swasta. Pada Tahun 2007, jumlah siswa yang terdaftar pada perguruan tinggi swasta tersebut sebanyak 1188, dan pada tahun 2008 meningkat sebanyak 2.131 siswa (Dinas Pendidikan Kabupaten Jeneponto, 2009). Untuk mengetahui jumlah lulusan Sekolah Menengah Tingkat Atas yang lulus selekasi Ujian Masuk
Perguruan Tinggi Negeri, dengan mengambil sampel SMA 1 Binamu sebagai sekolah unggulan, disajikan dalam Tabel 3 berikut:

Tabel 3.

Jumlah Siswa SMA 1 Binamu Kabupaten Jeneponto yang Lulus Seleksi Ujian Masuk Perguruan Tinggi Negeri dan PMDK Tahun 2002-2007

\begin{tabular}{|l|c|c|c|c|c|c|c|c|}
\hline \multirow{2}{*}{$\begin{array}{c}\text { PERGURUAN } \\
\text { TINGGI } \\
\text { NEGERI }\end{array}$} & \multicolumn{7}{|c|}{ T AH U N } \\
\cline { 2 - 9 } & $2002 / 2003$ & $2003 / 2004$ & $2004 / 2005$ & \multicolumn{2}{c|}{$2006 / 2007$} \\
\hline & PTN & PMDK & PTN & PMDK & PTN & PMDK & PTN & PMDK \\
\hline Unhas & 37 & - & & & & 24 & & 34 \\
\hline UNM & 28 & - & & 31 & & 28 & & 8 \\
\hline UGM & & - & & 18 & & & & 2 \\
\hline UNDIP & & - & & 1 & & 1 & & 1 \\
\hline IPB & & - & & 1 & & 1 & & \\
\hline Univ. Jember & & - & & 2 & & 1 & & \\
\hline UIN & & - & & 1 & 5 & & & 25 \\
\hline UNDIP & & - & & 25 & & & & \\
\hline IPB & & - & & & & & & \\
\hline UNTAD & & - & & & & 1 & & 1 \\
\hline POLTEK & & & & & & & & 25 \\
\hline Jumlah & 65 & $\mathbf{0}$ & $\mathbf{0}$ & $\mathbf{8 3}$ & $\mathbf{5}$ & $\mathbf{5 6}$ & $\mathbf{0}$ & $\mathbf{8 6}$ \\
\hline
\end{tabular}

Sumber Data Sekunder, SMA 1 Binamu Kabupaten Jeneponto, 2009

Rendahnya mutu pendidikan di Kabupaten Jeneponto juga dapat dilihat dari animo siswa untuk melanjutkan pendidikan pada perguruan tinggi khususnya perguruan tinggi negeri sangat rendah, seperti terlihat pada tabel 3 tersebut di atas, dimana pada tahun 2003 sampai dengan tahun 2006 sangat sedikit jumlah siswa yang melanjutkan pendidikan pada perguruan tinggi negeri, hal ini disebabkan kurangnya pemahaman mereka tentang pentingnya pendidikan untuk investasi masa depan, demikian menurut LY (wakil kepala sekolah bidang kesiswaan SMA 1 Binamu Kabupaten Jeneponto). Jumlah siswa yang melanjutkan pendidikan ke perguruan tinggi negeri tidak sebanding atau bahkan menunjukkan ketimpangan yang besar jika dibandingkan dengan jumlah siswa SMA 1 Binamu Kabupaten Jeneponto yang lulus Ujian Akhir Nasional dari Tahun 2002 sampai dengan Tahun 2007 yang mencapai angka kelulusan 100 persen.

Tabel 4.

Jumlah Siswa SMA 1 Binamu Kabupaten Jeneponto yang Lulus Ujian Akhir Nasional Tahun 2002-2007

\begin{tabular}{|c|c|c|c|c|c|c|c|}
\hline \multicolumn{7}{|c|}{ TAHUN } \\
\hline \multicolumn{2}{|c|}{$\mathbf{2 0 0 2 / 2 0 0 3}$} & \multicolumn{2}{|c|}{$\mathbf{2 0 0 3 / 2 0 0 4}$} & \multicolumn{2}{c|}{$\mathbf{2 0 0 4 / 2 0 0 5}$} & \multicolumn{2}{c|}{ 2006/2007 } \\
\hline Peserta & Lulus & Peserta & Lulus & Peserta & Lulus & Peserta & Lulus \\
\hline 378 & 378 & 370 & 370 & 304 & 304 & 282 & 282 \\
\hline
\end{tabular}

Sumber Data Sekunder, SMA 1 Binamu Kabupaten Jeneponto, 2009 
Tonggak-tonggak kunci keberhasilan sekolah dari segi output yang termaktub dalam standar nasional pendidikan, salah satu itemnya adalah dengan melihat banyaknya jumlah lulusan yang melanjutkan pendidikan ke jenjang yang lebih tinggi, dalam hal ini perguruan tinggi khususnya perguruan tinggi negeri. Rendahnya animo masyarakat untuk melanjutkan pendidikan juga merupakan salah satu indikator rendahnya mutu pendidikan.

Kelompok Kerja Pengkajian, Perumusan Filosofis kebijakan dan Strategi Pendidikan Nasional (1999) bahwa rendahnya mutu pendidikan di Indonesia selama ini disebabkan oleh beberapa faktor diantaranya (1) tidak adanya relevansi pendidikan dengan kebutuhan tenaga kerja, (2) tidak terjadinya proses belajar dengan baik, disebabkan kurang profesionalnya tenaga pengajar, (3) kurang tersedianya sarana dan prasarana yang memadai sebagai penunjang kegiatankegiatan pembelajaran, (4) pelaksanaan pendidikan selama ini bersifat sentralistik, sehingga mematikan potensi-potensi yang ada di daerah untuk mengembangkan pendidikan yang akan dilaksanakan. Walaupun guru dan pengajar bukan satusatunya faktor penentu keberhasilan pendidikan tetapi pengajaran merupakan titik sentral pendidikan dan kualifikasi atau kompetensi sebagai cermin kualitas pendidik memberikan andil yang sangat besar pada kualitas pendidikan. Guru punya peran yang sangat besar dalam menciptakan manusiamanusia handal. Menurut Hamalik (2006: 19) bahwa masalah pendidik dalam hal ini guru adalah masalah yang penting. Penting oleh sebab mutu pendidik turut menentukan mutu pendidikan. Sedangkan mutu pendidikan akan menentukan mutu generasi muda sebagai generasi penerus bangsa. Michael G. Fullan yang dikutip oleh Suyanto dan Hisyam (2000) mengemukakan bahwa:

\section{"Educational change depends on what teachers do and think..."}

Upaya peningkatan mutu pendidik dilakukan oleh pemerintah dengan lahirnya sebuah kebijakan yang tertuang dalam
Peraturan Daerah Nomor 4 Tahun 2006 tentang RPJM Kabupaten Jeneponto Tahun 2006-2008. Di dalam Perda tersebut tertuang uraian kebijakan yang ditempuh untuk meningkatkan mutu atau kompetensi pendidik yaitu di antaranya adalah peningkatan rasio pendidik dan tenaga kependidikan melalui pengangkatan, dan pemerataan penyebaran pendidik dan tenaga kependidikan. Tetapi dengan kebijakan itu, penulis melihat tidak banyak membawa perubahan pada kualitas pendidik di Kabupaten Jeneponto.

Berdasarkan latar belakang dan gambaran singkat mengenai keadaan tersebut disimpulkan bahwa kebijakan peningkatan kompetensi pendidik di Kabupaten Jeneponto tidak membawa perubahan yang signifikan terhadap kompetensi guru khususnya kompetensi profesional yang berdampak pada kemampuan akademik dan non akademik siswa yang rendah. Kebijakan peningkatan kompetensi pendidik yang tertuang dalam Perda Nomor 4 Tahun 2006 tentang RPJM Kabupaten Jeneponto berjalan sejak Tahun 2006, ternyata selama kurun waktu 20062008 kualitas anak didik menujukkan penurunan.

\section{B. LANDASAN TEORI}

\section{Implementasi Kebijakan Publik}

Implementasi kebijakan merupakan aspek penting dari keseluruhan proses kebijakan. Udoji $(1981,32)$ dengan tegas mengatakan bahwa the execution of policies is as important if not more important than policy-making. Policies will remain dreams or blue prints file jackets unless they are implemented (Pelaksanaan kebijakan adalah sesuatu yang penting, bahkan jauh lebih penting daripada pembuatan kebijakan. Kebijakan-kebijakan akan sekedar berupa impian atau rencana bagus yang tersimpan rapi dalam arsip kalau tidak diimplementasikan. Dengan kata lain pembuatan kebijakan tidak berakhir setelah kebijakan ditentukan atau disetujui.

Implementasi Kebijakan merupakan langkah lanjutan berdasarkan suatu kebijakan formulasi. Definisi yang umum dipakai menyangkut kebijakan implementasi adalah: 
(Wahab, 1997: 63) : "Implementasi adalah tindakan-tindakan yang dilakukan baik oleh individu-individu, pejabat-pejabat, atau kelompok-kelompok pemerintah atau swasta yang diarahkan pada tercapainya tujuantujuan yang telah digariskan dalam keputusan kebijakan.

Dunn $(1981 ; 56)$ menyatakan bahwa akan halnya implementasi kebijakan, lebih bersifat kegiatan praktis, termasuk di dalamnya mengeksekusi dan mengarahkan. Lebih lanjut dikemukakan sebagai berikut : "Policy implementation involves the execution and steering of a laws of action overtime. Policy implementation is essentially a practical activity, as distinguished from policy formulation, which is essentially theoretical'.

Sehubungan dengan sifat praktis yang ada dalam proses implementasi kebijakan di atas, maka hal yang wajar bahwa implementasi ini berkaitan dengan proses politik dan administrasi. Hal tersebut disebabkan karena ia menyangkut tujuan dari diadakannya kebijakan tersebut (policy goals). Dan jika dliihat dari konteks implementasi kebijakan, maka hal tersebut berkaitan dengan kekuasaan (power), kepentingan dan strategi para pelaku kebijakan, disamping karakteristik lembaga dan rezim serta ijin pelaksanaan dan respon terhadap kebijakan.

Konteks implementasi demikian baru akan terlihat pengaruhnya setelah kebijakan tersebut dilaksanakan. Hal itulah yang menunjukkan bahwa proses pelaksanaan kebijakan merupakan salah satu tahapan penting dan momentum dalam proses perumusan/pembuatan kebijakan selanjutnya, sebab berhasil atau tidaknya suatu kebijakan dalam mencapai tujuannya ditentukan dalam pelaksanaannya. Oleh karena itu, rumusan kebijakan yang telah dibuat tidak akan mempunyai arti apa-apa atau hanya akan merupakan rangkaian katakata indah dan baku yang tersimpan rapi dalam sebuah dokumen kalau tidak diimplementasikan. Berkaitan dengan hal itu, dapat dikatakan bahwa salah satu tolok ukur keberhasilan suatu strategi atau kebijakan terletak pada proses implementasinya.

Melihat pentingnya fase ini, maka untuk mencermati proses implementasi dari kebijakan tersebut, terlebih dahulu harus kita pahami beberapa konsep dari implementasi itu sendiri. Menurut Salusu (2002), implementasi adalah seperangkat kegiatan yang dilakukan menyusul satu keputusan. Suatu keputusan selalu dimaksudkan untuk mencapai sasaran. Guna merealisasikan pencapaian sasaran tersebut, diperlukan serangkaian aktivitas. Jadi dapat dikatakan bahwa implementasi adalah operasionalisasi dari berbagai aktivitas guna mencapai sasaran tertentu. Masih dalam Salusu (2002), Higgins merumuskan implementasi sebagai rangkuman dari berbagai kegiatan yang di dalamnya sumberdaya manusia menggunakan sumber daya lain untuk mencapai sasaran dan strategi. Sehingga kegiatan implementasi ini, menyentuh semua jajaran manajemen mulai dari manajemen puncak sampai pada karyawan lini paling bawah.

Pemahaman lebih lanjut tentang konsep implementasi dapat pula dilihat dari apa yang dikemukakan oleh Lineberry dalam Putra $(2003,81)$ dengan menguti pendapat Van Meter dan Van Horn (1975) yang memberikan pernyataan bahwa, Policy implementation encompasses those actions by public and private individuals (and groups) that are directed at the achievement of goals and objectives set forth in prior policy decisions. Pernyataan ini memberikan makna bahwa implementasi adalah tindakan-tindakan yang dilaksanakan oleh individu-individu, dan kelompok-kelompok pemerintah dan swasta yang diarahkan pada pencapaian tujuan dan sasaran yang menjadi prioritas dalam keputusan kebijakan. Secara sederhana dapat dikatakan bahwa implementasi meliputi semua tindakan yang berlangsung antara pernyataan kebijakan dan dampak aktualnya.

Pada bagian lain, mengenai pelaksanaan kebijakan, Hoogerwerf (1983 ; 17) mengemukakan sebagai berikut: "Bahwa pelaksanaan kebijakan itu hampir selalu harus disesuaikan lagi. Hal itu disebabkan karena tujuan dirumuskan terlalu umum, sarana tidak dapat diperoleh pada waktunya dan faktor waktu dipilih terlalu optimis, semua ini berdasarkan gambaran situasi yang kurang 
tepat. Dengan perkataan lain pelaksanaan kebijakan didalam praktek sering menjadi suatu proses yang berbelit-belit, yang menjurus kepada permulaan baru dari pada seluruh proses kebijakan atau menjadi buyar sama sekali".

Keberhasilan atau kegagalan suatu implementasi kebijakan dapat dievaluasi dari sudut kemampuannya secara nyata dalam meneruskan dan mengoperasionalkan program-program peningkatan kualitas pendidik secara ideal yang telah dirancang sebelumnya.

\section{Kebijakan Pendidikan dan Kompetensi Pendidik}

\section{Sekilas tentang Kebijakan Pendidikan}

Di dalam Pembukaan UUD 1945 dinyatakan bahwa tujuan kita membentuk negara kesatuan Republik Indonesia ialah untuk mencerdaskan kehidupan bangsa. Bangsa yang cerdas adalah bangsa yang dapat survive di dalam menghadapi berbagai kesulitan. Kenyataannya adalah dewasa ini bangsa Indonesia dilanda dan masih berada di tengah-tengah krisis yang menyeluruh. Kita dilanda oleh krisis politik, krisis ekonomi, krisis hukum, krisis kebudayaan, dan tidak dapat disangkal juga di dalam bidang pendidikan.

Pendidikan tidak terlepas dari politik sungguhpun pendidikan tidak dapat menggantikan fungsi politik. Kenyataannya ialah meskipun pendidikan tidak dapat menggantikan politik, tetapi tanpa pendidikan, tujuan-tujuan politik sulit untuk dilaksanakan. Oleh karena itu fungsi dan peranan pendidikan di dalam kehidupan suatu bangsa tidak terlepas dari kehidupan politik serta juga ekonomi, hukum dan kebudayaan pada umumnya.

Di dalam masa krisis dewasa ini ada dua hal yang menonjol menurut Tilaar $(2000 ; 1)$ yaitu: (1) bahwa pendidikan tidak terlepas dari keseluruhan hidup manusia di dalam segala aspeknya yaitu politik, ekonomi, hukum dan kebudayaan, (2) krisis yang dialami oleh bangsa Indonesia dewasa ini merupakan pula refleksi dari krisis pendidikan nasional.

Pada masa pra Orde Baru, politik dijadikan sebagai panglima. Segala kegiatan diarahkan kepada berbagai usaha untuk mencapai tujuan politik misalnya membangkitkan nasionalisme, rasa persatuan bangsa, penggalangan kekuatan bangsa di dalam kehidupan perang dingin pada waktu itu. Kecenderungan-kecenderungan dalam kehidupan politik, ekonomu dan kebudayaan pada waktu itu juga memasuki dunia pendidikan. Praktis pendidikan diarahkan kepada proses indoktrinasi. Dengan sendirinya pendidikan tidak difungsikan untuk meningkatkan taraf kehidupan rakyat. Pendidikan tida dioroientasikan pada kebutuhan pasar, tetapi pada kebutuhan politik. Pendidikan diarahkan bukan kepada peningkatan kualitas tetapi dijadikan sebagai alat kekuasaan dalam mencapai tujuan politik. Otoriterisme di dalam segala bentuknya mulai memasuki kehidupan bermasyarakat termasuk di dalam bidang pendidikan. Segala sesuatu diarahkan kepada kemauan penguasa, sehingga kebebasan berpikir, berpikir alternatif, berpikir kritis semakin lama semakin dikubur. Hasilnya ialah manusiamanusia yang tidak mempunyai alternatif yang telah disodorkan oleh penguasa.

Selanjutnya perkembangan pendidikan di Indonesia dapat dilihat bahwa segera setelah memperoleh kemerdekaannya, Indonesia telah menyatakan niatnya untuk menciptakan sistem pendidikan yang sesuai dengan kebutuhan dan aspirasinya. Perubahanperubahan yang terjadi dalam bidang pendidikan merupakan perubahan yang mendasar, yaitu menyangkut penyesuaian sistem pendidikan dengan kebutuhan dan aspirasi bangsa yang merdeka. Pada mulanya, penekanannya pada pemberian kesempatan yang seluas-luasnya kepada semua warga negara memperoleh pendidikan untuk menghasilkan sebanyak-banyaknya orang terdidik (Tilaar, 2000). Sekalipun tidak dimaksudkan mengabaikan mutu, tetapi dalam proses perkembangannya dari tahun ke tahun, tampaknya kebijakan perluasan kesempatan untuk memperoleh pendidikan kurang menguntungkan mutu pendidikan. 
Dari satu sisi, jumlah orang terdidik semakin meningkat, tetapi di sisi lain mutunya kurang memuaskan. Kita dihadapkan pada masalah rendahnya mutu pendidikan. Pada Tahun 1969, diadakan seminar identifikasi masalah pendidikan, dan menemukan lima masalah sebagai faktor kelemahan dalam pendidikan kita selama ini antara lain : (1) pertambahan penduduk yang demikian besarnya, (2) ketidakcocokan hasil sekolah dengan kebutuhan masyarakat, (3) sedikitnya biaya yang dapat disediakan oleh negaranegara yang sedang berkembang, (4) tidak adanya efisiensi kerja dan (5) kurang jelasnya arah pendidikan (Sahabuddin, 1997,42). Hasil identifikasi masalah pendidikan ini dijadikan landasan pelaksanaan pembaharuan pendidikan yang dimulai sejak tahun 1970 .

Usaha pembaharuan pendidikan yang berorientasi sekolah mengarah kepada pembaharuan kurikulum dan metode mengajar untuk mengembangkan kemampuan rasional. Anak didik diharapkan dapat berpikir, berkomunikasi serta bertiindak secara logis, analitis-sintetis, kritis dan kreatif. (Sahabuddin, 1997,43). Untuk mencapai tujuan tersebut, dikembangkan pendekatan yang memberi kesempatan kepada siswa-siswa untuk belajar aktif menurut minat dan kemampuan yang disebut Cara Belajar Siswa Aktif (CBSA).

Dalam perkembangan selanjutnya DEPDIKBUD mengembangkan kebijakan link and match dalam konteks strategi dasar pendidikan nasional. Link secara harifiah berarti ada pertautan, keterkaitan, atau hubungan interaktif. Dan match berarti kesesuaian. Link berarti hasil pendidikan selayak-nya sesuai dengan apa yang dibutuhkan oleh dunia kerja dari segi jumlah, mutu, jenis, kualifikasi dan waktunya. Match berarti sesuai dengan pihak lain, penguatan atau penekanan terhadap link.

Memasuki era reformasi, dengan pengalamanpengalaman masa lalu yang telah membentuk masyarakat dan budaya Indonesia yang kini mengalami krisis, maka tujuan nasional pendidikan diarahkan kepada tercapainya masyarakat Indonesia baru, yaitu masyarakat madani. Masyarakat madani adalah bentuk yang ideal dari suatu masyarakat demokratis dan berkedaulatan rakyat. Lahirnya UU No 32 Tahun 1999 yang kemudian direvisi menjadi UU No 32 Tahun 2004 tentang otonomi daerah dan UU No. 25 Tahun 1999 mengenai perimbangan keuangan pemerintah pusat dan daerah, merupakan konsekuensi dari keinginan era reformasi untuk menghidupkan kehidupan demokrasi (Tilaar, 2000, 12).

Dengan terbitnya Udang-Undang Otonomi Daerah, maka dimulailah salah satu rentetan proses demokratisasi di dalam kehidupan masyarakat dan bangsa Indonesia. Salah satu pelaksanaan dari Undang-Undang Otonomi Daerah adalah dalam bidang pendidikan. Penyelenggaraan pendidikan menjadi tugas dan wewenang daerah. Desentralisasi penyelenggaraan pendidikan di daerah memberikan implikasi langsung di dalam penyusunan dan penentuan kurikulum yang selama orde baru sangat sentralistis. Comunity based education serta school based education management merupakan perwujudan nyata dari demokratisasi dan desentralisasi pendidikan.

Di dalam kaitan ini pendidikan yang kita inginkan adalah pendidikan pemberdayaan yaitu yang bertujuan memberdayakan setiap anggota masyarakat untuk dapat berprestasi setinggi-tingginya sesuai dengan kemampuan yang telah dikembangkan di dalam dirinya sendiri. Kemudian pada tahun 2004-2005 diterapkan Kurikulum Berbasis Kompetensi (KBK). Kemudian pada Tahun 2006 sampai sekarang diterapkan Kurikulum Tingkat Satuan Pendidikan. Perubahan-perubahan kurikulum tersebut dilakukan sebagai salah satu upaya untuk meningkatkan mutu pendidikan.

Jika diperhatikan apa yang telah dikemukakan, tampak bahwa dalam perkembangan pendidikan di Indonesia telah banyak upaya yang ditempuh untuk meningkatkan mutu pendidikan. Demikian halnya di Kabupaten Jeneponto, Upaya untuk meningkatkan mutu pendidikan terlihat dari lahirnya kebijakan Pemerintah Daerah yang tertuang dalam Peraturan Daerah No. 4 Tahun 2006 tentang Rencana Pembangunan Jangka Menengah tahun 2006-2008. Di Dalam kebijakan tersebut termaktub program 
peningkatan kompetensi pendidik yang terdiri dari : (1) Peningkatan rasio pendidik dan tenaga kependidikan melalui pengangkatan, dan pemerataan penyebaran pendidik dan tenaga kependidikan, (2) Peningkatan kualitas pendidik dan tenaga kependidikan melalui Diklat dan (3) Pemberian penghargaan sesuai dengan tugas dan prestasi pendidik dan tenaga kependidikan.

Kebijakan tersebutlah yang akan diteliti bagaimana implementasinya di Kabupaten Jeneponto. Karena yang dilihat adalah kompetensi pendidik, maka selanjutnya akan dijelaskan sekilas tentang kompetensi.

\section{Kompetensi Profesional Pendidik}

Konsep Kompetensi sebagaimana yang dikutip Siswanto (2003) dijelaskan bahwa konsep kompetensi yang terkait dengan pekerjaan, pertama kali diangkat oleh David C. McClelland pada tahun 1973, ia mempublikasikan paper berjudul Testing for Competence rather than Intellegence" yang mengemukakan latar belakang dan konsep kompetensi dalam psikologi modern. Dalam paper tersebut, ia melakukan kajian dan metaanalisa berbagai penelitian sebelumnya, dan menyimpulkan bahwa pengukuran potensi intelegensi dan pengetahuan akademik dianggap kurang akurat untuk memprediksi prestasi kerja maupun keberhasilan dalam kehidupan sosial di masyarakat.

Disamping itu dikemukakan pula bahwa hasil psikotes dan nilai prestasi akademik yang diperoleh dari bangku sekolah dan perguruan tinggi seringkali diskriminatif terhadap gender, kelompok minoritas, ataupun menurut strata sosioekonomi. Hal ini memicu penelitian-penelitian babak baru untuk mencari metode-metode yang lebih baik untuk mengidentifikasikan kemampuan profesional dan kemampuan individu di tempat kerja, yang kemudian disebut sebagai kemampuan atau kompetensi.

Pengertian kompetensi dapat dijelaskan secara sederhana sebagai kemampuan manusia yang ditemukan dari praktek dunia nyata dapat digunakan untuk membedakan antara mereka yang sukses (superior) dengan yang biasa-biasa saja di tempat kerja. Kompetensi seseorang dapat ditunjukkan dengan hasil kerja atau karya, pengetahuan, keterampilan, perilaku, karakter, sikap, motivasi, dan/atau bakatnya.

Spencer and Spencer (1993: 9) mendefenisikan kompetensi "an underlying characteristic of individual that is causally related to criterion-referenced effective and/or superior performance in a job or situation". Sebagai karakteristik individu yang melekat kompetensi merupakan bagian dari kepribadian individu yang relatif dalam dan stabil, dan dapat dilihat serta diukur dari perilaku individu yang bersangkutan, di tempat kerja atau dalam berbagai situasi. Untuk itu kompetensi seseorang mengindikasikan kemampuan berperilaku seseorang dalam berbagai situasi yang cukup konsisten untuk suatu perioda waktu yang cukup panjang, dan bukan hal yang kebetulan sesaat semata. Kompetensi memiliki persyaratan yang dapat digunakan untuk menduga yang secara empiris terbukti merupakan penyebab suatu keberhasilan.

Sebagai karakteristik individu yang melekat, kompetensi nampak pada cara berperilaku di tempat kerja seseorang. Spencer (1993: 9-23) mengemukakan kompetensi dapat bersumber dari lima jenis sumber kompetensi yang berbeda yaitu:

(1)Motif. Sesuatu yang secara konsisten menjadi dorongan, pikiran atau keinginan seseorang yang menyebabkan munculnya suatu tindakan. Motif akan mengarahkan dan menyeleksi sikap menjadi tindakan atau mewujudkan tujuan sehingga berbeda dari yang lain.

(2) Karakter (trait) dan unsur bawaan. Karakter dan bawaan seseorang dapat mempengaruhi prestasi di tempat kerja. Karakter dan unsur bawaan ini dapat berupa bawaan fisik (seperti postur atletis, penglihatan yang baik), maupun bawaan sifat yang lebih kompleks yang dimiliki seseorang sebagai karakter, seperti kemampuan mengendalikan emosi, perhatian terhadap hal yang sangat detail dan sebagainya.

(3) Pengetahuan (knowledge). Pengetahuan mencerminkan informasi yang dimiliki 
seseorang pada area disiplin yang tertentu yang spesifik. Nilai akademis atau indeks prestasi akademis seringkali kurang bermanfaat untuk memprediksi performansi di tempat kerja, karena sulitnya mengukur kebutuhan pengetahuan dan keahlian yang secara nyata digunakan dalam pekerjaan. Pengetahuan dapat memprediksikan apa yang mampu dilakukan seseorang, bukan apa yang akan dilakukan. Hal ini disebabkan pengukuran tes pengetahuan lebih banyak menghafal, jika yang dipentingkan adalah kemampuan untuk mencari informasi. Ingatan mengenai fakta spesifik, tidak lebih penting daripada pengetahuan mengenai fakta yang relevan, terhadap masalah spesifik dan pengetahuan tentang sumber informasi dimana mencarinya ketika diperlukan. Tes pengetahuan juga sangat tergantung situasi responden. Tes tersebut mengukur kemampuan memilih alternatif pilihan, yang merupakan respon yang benar, dan bukan untuk mengukur apakah seseorang dapat bereaksi sesuai dengan pengetahuan dasarnya. Mengetahui sesuatu yang benar tidaklah selalu menjamin akan melakukan sesuatu yang benar.

(4) Keterampilan. Kemampuan untuk melakukan aktivitas fisik dan mental. Kompetensi keterampilan mental atau kognitif meliputi pemikiran analitis (memproses pengetahuan atau data, menentukan sebab dan pengaruh, mengorganisasi data dan rencana) serta pemikiran konseptual (pengenalan pola data yang kompleks).

Dari penjelasan diatas, dapat dipahami bahwa apa yang dilakukan seseorang di tempat kerja, hasil kerja apa yang diperoleh seseorang, dan tingkat prestasi kerja apa yang dicapai seseorang dapat bersumber dari karakteristik individu, yang dipengaruhi oleh salah satu atau kombinasi dari lima tipe sumber kompotensi yang berbeda. Dengan kata lain, pendekatan kompetensi ini meyakini bahwa perilaku efektif seseorang di tempat kerja atau pada suatu situasi tertentu merupakan cerminan kompotensi seseorang. Jika manusia merupakan sumber daya yang nyata, maka sumber daya yang dapat diberikannya adalah berupa keterampilan, pengetahuan, motivasi, dan kemampuan membuat keputusan. Proses identifikasi dan penilaiannya sangat komplek dan sulit sehingga hanya dapat diukur dari kinerja, pengalaman dan kualifikasi mereka.

Kompetensi pada dasarnya merupakan gambaran tentang apa yang seyogyanya dapat dilakukan (be able to do) seseorang dalam suatu pekerjaan, berupa kegiatan, perilaku dan hasil yang seyogyanya dapat ditampilkan atau ditunjukkan. Agar dapat melakukan (be able to do) sesuatu dalam pekerjaannya, tentu saja seseorang harus memiliki kemampuan (ablity) dalam bentuk pengetahuan (knowledge), sikap (attitude) dan keterampilan (skill) yang sesuai dengan bidang pekerjaannya. Kompetensi guru dapat dimaknai sebagai gambaran tentang apa yang seyogyanya dapat dilakukan seorang guru dalam melaksanakan pekerjaannya, baik berupa kegiatan, berperilaku maupun hasil yang dapat ditunjukkan.

Dalam perspektif kebijakan pendidikan nasional, pemerintah telah merumuskan empat jenis kompetensi guru sebagaimana tercantum dalam Penjelasan Peraturan Pemerintah Nomor 14 Tahun 2005 tentang Standar Nasional Pendidikan, yaitu : kompetensi pedagogik, Kompetensi kepribadian, Kompetensi sosial, dan kompetensi profesional merupakan kemampuan penguasaan materi pembelajaran secara luas dan mendalam.

Indikator tentang kompetensi professional guru yang disampaikan oleh Hamalik (2002) mengandung makna bahwa guru yang memiliki kompetensi professional adalah guru yang mampu menciptakan lingkungan belajar yang efektif, menyenangkan dan akan lebih mampu mengelola kelasnya sehingga siswa akan belajar secara optimal. Untuk itu sehubungan dengan peranan guru sebagai pendidik dan pengajar diperlukan keterampilan-keterampilan yang dibutuhkan untuk kelancaran proses belajar mengajar antara lain:

(1) keterampilan membuka pelajaran pelajaran, (2) keterampilan menjelaskan atau menyampaikan materi pelajaran, (3) keterampilan member penguatan, (4) 
keterampilan menggunakan media pembelajaran, (5) keterampilan membimbing diskusi kelompok kecil, (6) keterampilan menutup pelajaran. Dalam penelitian ini yang digunakan hanya 4 indikator yaitu (1) keterampilan membuka pelajaran, (2) keterampilan menyampaikan materi pelajaran, (3) keterampilan menggunakan media pembelajaran dan (4) kete-rampilan menutup pelajaran. (Hamalik,2002).

\section{HASIL PENELITIAN DAN PEMBAHASAN}

Pada kebijakan ini, peningkatan rasio pendidik dimaksudkan untuk menutupi kekurangan guru dengan melakukan rekruitment atau pengangkatan pendidik. Kemudian Pemerataan penyebaran pendidik dimaksudkan untuk meminimalkan atau mengeliminir kesenjangan antara sekolah unggulan dengan sekolah-sekolah yang tidak diunggulkan, atau antara sekolah yang berada di kota maupun sekolah yang ada di Kecamatan. Kegiatan yang dapat dilakukan untuk maksud tersebut adalah mutasi.

\section{a. Kebijakan Rekrutmen Pendidik.}

Di dalam Peraturan Pemerintah Republik Indonesia Nomor 74 Tahun 2008 tentang guru dikatakan bahwa rasio minimal jumlah peserta didik terhadap guru untuk SMA atau yang sederajat adalah 20: 1. Kemudian selanjutnya pada Bab IV Pasal 52 Peraturan Pemerintah Republik Indonesia Nomor 74 tahun 2008 tentang guru mengatur jumlah beban kerja guru paling sedikit 24 jam tatap muka dalam satu minggu pada satu atau lebih satuan pendidikan yang memiliki izin pendirian dari Pemerintah atau Pemerintah Daerah.

Sehingga jumlah kekurangan dan kelebihan guru dapat diketahui dengan terlebih dahulu mengetahui jumlah rombongan belajar dan jumlah jam, dengan tetap mengacu kepada aturan bahwa jumlah maksimal siswa per rombongan belajar adalah 40 (empat puluh siswa), kemudian jumlah jam wajib mengajar bagi guru adalah 24 (dua puluh empat) jam per minggu, dan jumlah jam pelajaran per kelas setiap minggu adalah antara 38 sampai dengan 42 jam.

Selain itu menurut ND bahwa: Secara kongrit jumlah kekurangan dan kelebihan guru di setiap sekolah dapat diketahui dengan mengacu pada Peraturan Pemerintah Nomor 74 Tahun 2008 tentang guru Bab IV Pasal 52. Berikut akan diuraikan secara singkat mengetahui jumlah kekurangan dan kelebihan guru pada SMA 1 Tamalatea sebagai sampel. SMA 1 Tamalatea Kabupaten Jeneponto mempunyai 7 kelas X, 3 kelas XI IPA, 1 kelas XI Bahasa, dan 2 kelas XI IPS, demikian pula untuk kelas XII terdiri dari XII IPA sebanyak 3 kelas, XII Bahasa sebanyak 1 kelas, dan XII IPS sebanyak 3 kelas.

Sehingga jumlah rombongan belajar secara keseluruhan adalah 20 rombel. Untuk Mata Pelajaran Sosiologi jumlah kelasnya 12 kelas/rombongan belajar, dan jumlah jam mengajar 36 jam per minggu, sehingga diketahui bahwa jumlah guru yang dibutuhkan adalah 2 orang guru sosiologi berdasarkan aturan bahwa setiap guru wajib memenuhi 24 jam mengajar perminggu, sehingga 36 jam dibagi dengan 24 jam sama dengan 2 orang. Sementara di SMA 1 Tamalatea tidak mempunyai guru mata pelajaran sosiologi sehingga dikatakanlah bahwa SMA 1 Tamalatea Kekuarangan 2 orang guru sosiologi. (wawancara Oktober 2009).

Berdasarkan hal tersebutlah sehingga diketahui bahwa jumlah kekurangan guru di Kabupaten Jeneponto kurun waktu 20062008 adalah 84 orang guru, disisi lain juga berkelebihan 20 guru. Untuk menutupi kekurangan guru maka kegiatan yang dilakukan adalah meningkatkan rasio pendidik agar memenuhi standar dengan melakukan rekrutment atau pengangkatan pendidik.

Sebagaimana yang diatur dalam Peraturan Pemerintah Republik Indonesia Nomor 74 Tahun 2008 tentang Guru, Bab VI pasal 59 ayat 3 menyatakan bahwa dalam hal terjadi kokosongan guru, pemerintah atau pemerintah daerah wajib menyediakan guru pengganti untuk menjamin keberlanjutan proses pembelajaran pada satuan pendidikan yang bersangkutan. Sehingga atas dasar tersebut, diadakanlah pengangkatan. 
Tabel 5.

Jumlah Kekurangan dan Rekrutment Guru di Sekolah SMAN Kabupaten Jeneponto Kurun Waktu 2006-2008

\begin{tabular}{|c|c|c|c|c|}
\hline \multirow{2}{*}{ SEKOLAH } & \multicolumn{2}{|l|}{ KEKURANGAN } & \multicolumn{2}{|c|}{ REKRUITMEN } \\
\hline & Mata Pelajaran & $\mathrm{Jml}$ & Mata Pelajaran & $\mathrm{Jml}$ \\
\hline SMA 1 Binamu & $\begin{array}{l}\text { 1. Seni Budaya } \\
\text { 2. Ekonomi } \\
\text { 3. Biologi } \\
\text { 4. Matematika } \\
\text { 5. Bahasa Ingris } \\
\text { 6. Bahasa Indonesia } \\
\text { 7. Penjas } \\
\text { 8. Kima } \\
\text { 9. Sosiologi }\end{array}$ & $\begin{array}{l}2 \\
2 \\
2 \\
2 \\
2 \\
2 \\
2 \\
1 \\
1\end{array}$ & $\begin{array}{l}\text { 1. Bahasa Ingris } \\
\text { 2. Bahasa Indonesia } \\
\text { 3. Penias } \\
\text { 4. Sosiologi }\end{array}$ & $\begin{array}{l}1 \\
1 \\
1 \\
1\end{array}$ \\
\hline Jumlah & & 16 & Jumlah & 4 \\
\hline SMA 2Binamu & 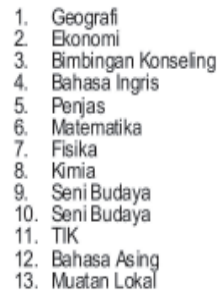 & $\begin{array}{l}2 \\
2 \\
2 \\
1 \\
1 \\
1 \\
1 \\
1 \\
1 \\
1 \\
1 \\
1 \\
1\end{array}$ & 1. Ekonomi & 1 \\
\hline Jumlah & & 15 & Jumlah & 1 \\
\hline SMA 1 Tamalatea & $\begin{array}{l}\text { 1. Sosiologi } \\
\text { 2. TIK } \\
\text { 3. Sastra Indonesia } \\
\text { 4. Antropolog }\end{array}$ & $\begin{array}{l}2 \\
2 \\
2 \\
1\end{array}$ & $\begin{array}{l}\text { 1. Bahasa Ingris } \\
\text { 2. Sejarah }\end{array}$ & 1 \\
\hline Jumlah & & 7 & & 3 \\
\hline SMA 1 Bangkala & 1. Ekonomi & 1 & $\begin{array}{ll}\text { 1. } & \text { PPKN } \\
\text { 2. } & \text { Bahasa Daerah } \\
\text { 3. } & \text { Bahasa Indonesia }\end{array}$ & $\begin{array}{l}1 \\
1 \\
1\end{array}$ \\
\hline Jumlah & & 1 & & 3 \\
\hline $\begin{array}{l}\text { SMA } 1 \text { Bangkala } \\
\text { Barat }\end{array}$ & $\begin{array}{l}\text { 1. BP/BK } \\
\text { 2. Laboran } \\
\text { 3. Agama } \\
\text { 4. Sejazah } \\
\text { 5. Bahasa Ingris } \\
\text { 6. Penjas } \\
\text { 7. Matematika } \\
\text { 8. Geografi }\end{array}$ & $\begin{array}{l}2 \\
2 \\
1 \\
1 \\
1 \\
1 \\
1 \\
1 \\
1\end{array}$ & $\begin{array}{ll}\text { 1. } & \text { Agama } \\
\text { 2. } & \text { Matematika } \\
\text { 3. BK } \\
\text { 4. Bahasa Ingris }\end{array}$ & $\begin{array}{l}1 \\
1 \\
1 \\
1\end{array}$ \\
\hline Jumlah & & 10 & & 4 \\
\hline
\end{tabular}

\begin{tabular}{|c|c|c|c|c|}
\hline \multirow{2}{*}{ Sekolah } & \multicolumn{2}{|l|}{ Kekurangan } & \multicolumn{2}{|c|}{ Rekruitmen } \\
\hline & Mata Pelajaran & Jml & Mata Pelajaran & $\mathrm{Jml}$ \\
\hline $\begin{array}{l}\text { SMA } 1 \\
\text { Batang }\end{array}$ & $\begin{array}{l}\text { 1. Kewarganegaraan } \\
\text { 2. Matematika } \\
\text { 3. Sosiologi } \\
\text { 4. BP/BK } \\
\text { 5. Bahasa Indonesia } \\
\text { 6. Bahasa Ingris } \\
\text { 7. Kesenian } \\
\text { 8. Sejarah } \\
\text { 9. Fisika } \\
\text { 10. TIK } \\
\text { 11. Bahasa Asing } \\
\text { 12. BTQ }\end{array}$ & $\begin{array}{l}2 \\
2 \\
2 \\
2 \\
1 \\
1 \\
1 \\
1 \\
1 \\
1 \\
1 \\
1 \\
1\end{array}$ & 1. Kimia & 1 \\
\hline Jumlah & & 16 & & 1 \\
\hline $\begin{array}{l}\text { SMA } 1 \\
\text { Kelara }\end{array}$ & $\begin{array}{l}\text { 1. Bahasa Ingris } \\
\text { 2. Biologi } \\
\text { 3. TIK } \\
\text { 4. Bahasa Arab } \\
\text { 5. BTQ } \\
\text { 6. Bahasa Makassar } \\
\text { 7. BK } \\
\text { 8. Kesenian } \\
\text { 9. Sejarah } \\
\text { 10. Sosidogi }\end{array}$ & $\begin{array}{l}2 \\
2 \\
2 \\
2 \\
2 \\
2 \\
4 \\
1 \\
1 \\
1\end{array}$ & $\begin{array}{l}\text { 1. Matematika } \\
\text { 2. Seni } \\
\text { 3. Sudaya } \\
\text { 4. Bahologi } \\
\text { 4. Bahasa } \\
\text { Ingris }\end{array}$ & $\begin{array}{l}1 \\
1 \\
1 \\
1\end{array}$ \\
\hline Jumlah & & 19 & & 4 \\
\hline $\begin{array}{c}\text { Jumbah } \\
\text { Total }\end{array}$ & & 84 & Jumlah & 20 \\
\hline
\end{tabular}

Sumber: Dinas Pendidikan Kabupaten Jeneponto
Berdasarkan Tabel 5 tersebut di atas, dapat diketahui bahwa pengangkatan dan penempatan guru dari Tahun 2006 sampai dengan Tahun 2008 sejumlah 20 orang yang tersebar pada 7 sekolah SMA di Kabupaten Jeneponto. Jumlah ini sangat sedikit jika dibandingkan dengan jumlah kekurangan guru yang harus dipenuhi sebanyak 84 orang. Padahal dalam standar pelayanan minimal pendidikan ditetapkan bahwa sekolah dikatakan memenuhi standar jumlah pendidik jika telah memenuhi minimal 90 persen dari kebutuhan tenaga guru dan tenaga kependidikan lainnya. Dari Tabel 5 tersebut di atas juga dapat dilihat bahwa guru-guru yang direkrut tidak sesuai dengan kebutuhan baik jumlah maupun kualifikasi mata pelajaran.

Di SMA 1 Tamalatea misalnya, perekrutan yang dilakukan tidak sesuai dengan kebutuhan, dimana kekurangan 7 guru mata pelajaran justru yang direkrut adalah Bahasa Ingris dan Sejarah yang sebenarnya sudah surplus guru untuk mata pelajaran tersebut. Demikian juga di SMA 1 Bangkala yang kekurangan 1 orang guru mata pelajaran Ekonomi, tetapi yang direkrut tidak sesuai dengan yang dbutuhkan yaitu 3 orang guru mata pelajaran antara lain: PPKN, Bahasa Daerah dan Bahasa Indonesia.

Di sekolah lainnya, walaupun sudah sesuai dengan kebutuhan tetapi masih ada kebutuhan guru yang tidak direkrut. Misalnya di SMA 2 Binamu yang kekurangan 15 guru mata pelajaran, dan yang direkrut adalah guru mata pelajaran Ekonomi, sesuai dengan kebutuhan tetapi masih ada kebutuhan guru mata pelajaran yang tidak direkrut sebanyak 14 orang guru.

Demikian halnya di SMA 1 Bangkala Barat yang kekurangan 10 guru mata pelajaran, namun yang direkrut hanya 4 orang guru mata pelajaran. Meskipun yang direkrut sudah sesuai dengan kebutuhan tetapi masih ada kebutuhan guru mata pelajaran yang tidak direkrut sebanyak 6 orang.

Pada Tabel 5 tersebut di atas juga memperlihatkan bahwa terdapat sekolah yang perekrutannya tidak sesuai dengan jumlah yang dan kualifikasi guru mata pelajaran yang 
dibutuhkan. Hal ini terjadi pada SMA 1 Batang yang kekurangan 16 guru mata pelajaran, tetapi justru yang direkrut adalah guru mata pelajaran Kimia yang sebenarnya sudah terisi. Berdasarkan informasi yang disajikan pada Tabel 8 tersebut dapat dicermati bahwa perekrutan guru yang dilakukan masih semrawut sehingga jumlah guru yang direkrut tidak menutupi jumlah kekurangan guru dan yang memprihatinkan adalah terjadinya surplus guru pada satu sekolah karena yang direkrut tidak sesuai dengan kebutuhan.

Berkaitan dengan hal tersebut, kami konfirmasikan pada kepala bidang ketenagaan Dinas Pendidikan Kabupaten Jeneponto, dan beliau mengemukakan bahwa; Jumlah guru yang diangkat tidak sesuai dengan yang dibutuhkan karena data tentang daftar keadaan guru setiap sekolah belum akurat.selain itu formasi dari BKN (Badan Kepegawaian Negara) terbatas sehingga pengangkatan guru yang dilaksanakan bertahap. (HK, wawancara Maret 2010).

Dari hasil wawancara tersebut dapat diketahui bahwa untuk memenuhi prinsip sangkil mangkus dalam perekrutan guru, keakuratan data tentang kebutuhan guru di setiap sekolah khususnya sekolah SMA di Kabupaten Jeneponto sangat dibutuhkan, karena formasi pengangkatan guru dari Badan Kepegawaian Negara (BKN) terbatas.

Tabel 6.

Tanggapan Responden terhadap Upaya Melaksanakan Kebijakan Peningkatan Kompetensi Pendidik melalui Upaya Perekrutan dan Penyebaran Guru di Kabupaten Jeneponto

\begin{tabular}{|l|l|c|c|}
\hline No. & Tanggapan Responden & Frekuensi & Prosentase \\
\hline $\mathbf{1}$ & Sangat Serius & 3 & 3,4 \\
\hline $\mathbf{2}$ & Serius & 34 & 38,2 \\
\hline $\mathbf{3}$ & Kurang Serius & 47 & 52,8 \\
\hline $\mathbf{4}$ & Tidak serius & 5 & 5.6 \\
\hline $\mathbf{5}$ & Sangat tidak serius & - & - \\
\hline Jumlah & & 89 & 100 \\
\hline
\end{tabular}

Sumber: Hasil Olahan Kuesioner, 2009

Berdasarkan Tabel 6 tersebut di atas, bahwa secara umum responden yaitu 53 orang atau sekitar 58,4 \% yang mengatakan bahwa pemerintah masih belum serius dalam mengimplementasikan kebijakan peningkatan kompetensi pendidik di Kabupaten Jeneponto, melalui upaya pengangkatan dan penyebaran guru di sekolah-sekolah SMA se Kabupaten Jeneponto.

Pendapat tersebut didasarkan pada kenyataan bahwa belum terjadi pemerataan pendidik antar sekolah sehingga yang terjadi banyak sekolah-sekolah yang kekurangan guru, sementara disisi lain sekolah juga mempunyai kelebihan guru mata pelajaran yang diakibatkan karena pengangkatan guru tidak didasarkan pada prinsip proporsional dan profesional.

Responden yang mengatakan serius berjumlah 37 orang atau sekitar 41,62 persen dengan pertimbangan bahwa hampir setiap tahun kurun waktu 2006-2008 diadakan seleksi penerimaan guru untuk menutupi kekurangan guru, hanya faktor anggaran yang terbatas yang menjadi kendala terimplementasinya kebiijakan tersebut secara efektif. Hal ini sesuai dengan yang dikemukakan oleh Kepala Bidang Ketenagaan dalam wawancara kami bahwa;

Dalam setiap meeting dengan Bupati, beliau selalu menyampaikan pentingnya menata kembali penempatan guru. Distribusi guru yang sembrawut menjadi salah satu indikator penghalang peningkatan mutu pendidikan. Sehingga pengangkatan guru dilakukan untuk mencukupi kebutuhan guru. Hal ini telah dilakukan kurun waktu 20062008, hanya saja masih mengalami kendala setelah pengangkatan dan penempatan dilakukan, tidak berapa lama kemudian guru tersebut dengan berbagai alasan misalnya jauh dari tempat tinggal, akhirnya meminta pindah. Keadaan seperti ini bermuara pada terjadinya ketimpangan jumlah guru di satu sekolah dengan sekolah lain. Padaha apabila tertata dengan baik guru tidak lagi menumpuk di sekolah-sekolah tertentu dan terletak di dalam kota, tetapi sudah bisa merata ke seluruh pelosok. (HK,Wawancara Agustus,2009).

Hal berbeda dikemukakan oleh dengan Koordinator Pengawas SMA Kabupaten Jeneponto dalam wawancara penulis berkaitan dengan pengangkatan dan penyebaran guru di Kabupaten Jeneponto yang menganggap masih kurang serius;

Berkaitan dengan peningkatan rasio pendidik melalui pengangkatan dan 
penyebaran guru di Jeneponto, selama ini belum proporsional, hal yang perlu dilakukan adalah menata pemerataan guru terlebih dahulu sehingga tersebar secara merata disemua sekolah-sekolah SMA, sebaiknya mereposisi dulu kemudian merekrut guru sesuai dengan kebutuhan. (DT, Wawancara, Juli, 2009).

Pernyataan dari sebagian besar kepala sekolah SMA Kabupaten Jeneponto, setelah kami konfirmasikan kepada Kepala Dinas Pendidikan, Pemuda dan Olahraga Kabupaten Jeneponto juga mengakui bahwa masih adanya masalah kekurangan guru dan belum meratanya distribusi guru ke di setiap sekolah, berikut petikan wawancara kami:

Salah satu kendala yang kami alami sekarang ini adalah soal pemerataan guru, beberapa sekolah masih kekurangan guru mata pelajaran yang mengajar sesuai kompetensinya. Dalam beberapa kali penerimaan CPNS, guruguru yang diangkat kemudian ditempatkan sesuai dengan SK justru jauh dari harapan. Kerena faktor kedekatan emosional sehingga mudah meminta pindah ke sekolah lain, yang dianggap strategi. (Wawancara, Agustus,2009).

Wawancara tersebut memberikan gambaran bahwa pemerintah sepertinya masih kesulitan memenuhi atau mengimplementasikan kebijakan ini, juga menimbulkan suatu asumsi bahwa kebijakan peningkatan kompetensi pendidik belum menjadi masalah prioritas. Upaya pengangkatan dan penyebaran pendidik belum proporsional karena tidak didasarkan pada pertimbangan kebutuhan sekolah sehingga masih terjadi krisis guru sekaligus surplus guru yang terjadi di semua sekolah. Terdapat kemungkinan ada unsur kekerabatan sehingga ditempatkan pada sekolah yang strategis tetapi perlu diteliti lebih jauh.

Kendala lain yang dihadapi berkaitan dengan perekrutan pendidik di Kabupaten Jeneponto adalah tempat domisili atau letak tempat tinggal dengan sekolah (seperti yang dikemukakan oleh Kepala Bidang Ketenagaan Dinas Pendidikan Kabupaten Jeneponto dalam wawancara kami sebelumnya, halaman 150). Ada kecenderungan bahwa pendidik di Kabupaten Jeneponto yang ditempatkan disekolah yang jauh dari tempat tinggal mereka akan meminta pindah. Sebagaimana yang dikemukakan oleh AN (Agustus, 2009) bahwa:

Guru-guru akan meminta pindah mengajar jika letak sekolah tempatnya mengajar jauh dari tempat tinggalnya, sehingga diharapkan kedepan pemerintah memperhatikan kedekatan jarak geografis sekolah dengan tempat tinggal guru-guru sehingga hal-hal yang tidak diinginkan bisa dihindari, karena biasanya belum setahun ditugaskan di sekolah bersangkutan, mereka sudah meminta pindah dan yang memprihatinkan adalah mereka datang dan pergi tanpa sepengetahuan Kepala Sekolah, secara tiba-tiba saja SK penempatan di sekolah baru sudah ada tanpa ada informasi awal dan sepengetahuan Kepala sekolah sebelumnya. Di sekolah kami SMA 1 Turatea yang hanya memiliki 9 orang guru tetap, karena terdapat 3 orang guru tetap yang pindah mengajar masing-masing ke SMA khusus dan SMA 1 Binamu sehingga jumlah kekurangan guru di sekolah kami meningkat.

Hasil wawancara tersebut menggambarkan bahwa kebijakan penyebaran dan pemerataan pendidik dengan memperhatikan letak geografis tempat tinggal dengan tempat mengajar belum dilaksanakan secara maksimal, padahal menurut Saydam (1996: 99) penting untuk menjamin lingkungan kerja yang mendukung, karena dengan lingkungan pekerjaan yang nyaman membuat pegawai bekerja tenang, bersemangat dan bergairah dalam melaksanakan pekerjaan. Sebagaimana tanggapan US bahwa:

Pendidik yang bekerja pada sekolah yang jauh dari tempat tinggalnya akan merasa tidak nyaman, sehingga semangat kerjanya menurun. Hal ini pula yang menyebabkan sering terlambat mengajar. (Wawancara Agustus 2009).

Masalah lain berkaitan dengan belum optimalnya upaya perekrutan guru, dari olahan data sekunder dapat diketahui bahwa pada pengangkatan guru SMA Tahun 2006 ditemukan data guru yang mengajarkan dua mata pelajaran dan ironisnya adalah mengajarkan mata pelajaran yang berbeda dengan kualifikasi dan kompetensinya. Setelah hal ini kami konfrontasikan dengan Kepala 
Sekolah SMA 1 Tamalatea Kabupaten Jeneponto, beliau mengemukakan bahwa;

Untuk keberlangsungan Proses Belajar Mengajar, agar kelas tidak kosong akibat belum terpenuhinya kuota guru yang dibutuhkan, maka selain mengandalkan guru tidak tetap (GTT), juga kami membebani kepada guru yang dianggap bisa meskipun tidak sesuai dengan basic ilmu yang dimilikinya. (Wawancara, BM, Agustus, 2009).

Dari beberapa fenomena yang telah dijelaskan maka dapat disimpulkan bahwa bahwa pengangkatan guru tidak berakibat pada terwujudanya kebijakan peningkatan rasio pendidik pada sekolah SMA Kabupaten Jeneponto secara optimal. Perekrutan yang dilakukan tidak sesuai dengan kebutuhan baik dari kuantitasanya (proporsional) maupun kualifikasi guru mata pelajaran yang dibutuhkan (profesional). Perlu diketahui bahwa kebijakan pengangkatan dan pemerataan penyebaran pendidik merupakan salah satu faktor yang berpengaruh terhadap peningkatan kompetensi pendidik di Kabupaten Jeneponto. Hal ini didasarkan pada pertimbangan bahwa apabila penataan guru dilakukan secara proporsional, maka tidak ada lagi sekolah yang mengalami surplus dan krisis guru, sehingga proses belajar mengajar akan berlangsung secara efektif dan secara tidak langsung berakibat pada meningkatnya kompetensi guru sesuai dengan tuntutan perkembangan Ilmu pengetahuan dan perkembangan masyarakat.

Sekolah yang mengalami surplus guru mata pelajaran, terdapat kecenderungan bahwa guru mata pelajaran akan sulit memenuhi beban kerja kerja wajib per minggu yaitu 24 jam yang juga merupakan salah satu upaya meningkatkan kompetensi profesional guru. Selanjutnya, kegiatan yang dilakukan dalam rangka mengimplementasikan kebijakan penyebaran pendidik adalah mutasi. Berikut diuraikan bagaimana pelaksanaan mutasi pendidik SMA di Kabupaten Jeneponto. Mutasi dilaksanakan dalam upaya pemerataan penyebaran guru, agar tidak terjadi disparitas yang menonjol antara satu sekolah dengan sekolah yang lain.

\section{b. Kebijakan Mutasi Pendidik}

Mutasi dilaksanakan dalam upaya pemerataan penyebaran guru antara sekolahsekolah yang berada di kota maupun sekolah yang ada di kecamatan, serta antara sekolah yang surplus pendidiknya dengan sekolah yang krisis pendidik.

Tabel 7.

Distribusi Jumlah kekurangan dan Kelebihan Guru Mata Pelajaran Tingkat SMA di Kabupaten Jeneponto

\begin{tabular}{|c|l|c|c|c|}
\multirow{2}{*}{ No } & \multirow{2}{*}{ Nama Sekolah } & \multicolumn{2}{|c|}{ JUMLAH } & Kekurangan \\
& & $\begin{array}{c}\text { Kelebihan } \\
\text { Guru }\end{array}$ & $\begin{array}{c}\text { JUMLAH } \\
\text { Guru }\end{array}$ \\
\hline $\mathbf{1 .}$ & SMA 1 Binamu & 16 & 4 & $\mathbf{5 6}$ \\
\hline $\mathbf{2 .}$ & SMA 2 Binamu & 15 & 2 & $\mathbf{3 5}$ \\
\hline $\mathbf{3 .}$ & SMA 1 Tamalatea & 7 & 9 & $\mathbf{4 5}$ \\
\hline $\mathbf{4 .}$ & SMA 1 Bangkala & 1 & 2 & $\mathbf{2 0}$ \\
\hline $\mathbf{5 .}$ & SMA 1 Bangkala Barat & 10 & 1 & $\mathbf{1 8}$ \\
\hline $\mathbf{6 .}$ & SMA 1 Batang & 16 & 1 & $\mathbf{1 5}$ \\
\hline $\mathbf{7 .}$ & SMA 1 Kelara & 19 & 1 & $\mathbf{2 8}$ \\
\hline & Jumlah & $\mathbf{8 4}$ & $\mathbf{2 0}$ & $\mathbf{2 1 7}$ \\
\hline
\end{tabular}

Sumber: Dinas Pendidikan Kabupaten Jeneponto

Berdasarkan Tabel 7 tersebut di atas, diketahui bahwa pemerataan guru masih belum terbenahi dengan baik yang disebabkan karena guru-guru yang direkrut tidak sesuai dengan kebutuhan, kemudian tidak ditempatkan pada sekolah yang kekurangan sehingga mengakibatkan setiap sekolah disamping kekurangan guru juga sekaligus kelebihan guru mata pelajaran. Sebagai penguatan atas indikasi tersebut dari laporan bulanan sekolah SMA di Kabupaten Jeneponto diketahui bahwa:

SMA 1 Binamu kekurangan 16 guru yang dapat dirinci menurut mata pelajaran (lihat Tabel 7), padahal disisi lain, SMA 1 Binamu kelebihan 4 guru untuk Mata Pelajaran Sejarah yang kelebihan 1 orang guru, Mata Pelajaran Fisika kelebihan 2 orang guru, dan Mata Pelajaran Geografi kelebihan 1 orang guru. Sekolah SMA 2 Binamu kekurangan 15 Guru yang dapat dirinci menurut Mata pelajaran (lihat Tabel 7), sementara disisi lain kelebihan 2 guru Mata Pelajaran Bahasa Indonesia. Sekolah SMA 1 Tamalatea kekurangan 7 orang guru untuk Mata Pelajaran (lihat Tabel 7) disisi lain, SMA 1 Tamalatea kelebihan 9 orang guru 
yang dapat dirinci untuk Mata Pelajaran Agama kelebihan 3 orang guru, dan untuk Mata Pelajaran Geografi, Biologi, Bahasa Ingris, Sejarah, PPKN, dan Kimia masing-masing kelebihan 1 orang guru. Ironisnya, terdapat penempatan 2 guru bidang studi Bahasa Ingris di SMA 1 Tamalatea padahal sudah kelebihan 1 guru Bahasa Inggris.

Demikian halnya di SMA 1 Bangkala kekurangan 1 guru Mata Pelajaran Ekonomi dan kelebihan 2 guru masing-masing untuk mata pelajaran Bahasa Ingris dan Biologi. Sedangkan di SMA 1 Bangkala Barat kekurangan 10 guru mata pelajaran (lihat Tabel 7), disisi lain SMA 1 Bangkala Barat kelebihan 1 orang guru mata pelajaran Bahasa Jerman. Penempatan 3 orang guru mata pelajaran, masing-masing Bahasa Indonesia, PPKN dan Bahasa Daerah dianggap tidak proporsional karena SMA 1 Bangkala hanya kekurangan 1 guru ekonomi.

Keadaan guru SMA 1 Batang juga kekurangan 16 guru mata pelajaran (lihat rinciannya pada Tabel 7). Disisi lain SMA 1 Batang hanya kelebihan 1 guru untuk mata pelajaran Penjas. Pada pengangkatan Guru kurun waktu 2006 sampai 2008 hanya 1 orang guru yaitu mata pelajaran kimia yang ditempatkan di SMA 1 Batangi sehingga sekolah ini masih mengalami kekurangan guru yang signifikan. Terakhir, pada SMA 1 Kelara yang kekurangan 19 guru (lihat rincian pada Tabel 7) . Pengangkatan guru tidak menutupi jumlah kekurangan guru di sekolah tersebut, karena pada Tahun 2007 dan 2008 hanya ada 4 orang guru yang ditempatkan pada SMA 1 Kelara.

Kegiatan yang dapat dilakukan untuk menata penyebaran pendidik agar dapat terdistribusi secara proporsional adalah dengan melakukan mutasi. Tetapi Kenyataan yang peneliti temukan di lapangan, pada tahun 2006 dan 2007 mutasi tidak dilaksanakan. Hal ini sesuai pula dengan yang dikemukakan oleh informan bahwa;

Pada tahun 2006 dan 2007 tidak ada mutasi untuk guru-guru, yang sering dilakukan adalah mutasi kepala sekolah. Nanti pada tahun 2008 baru ada mutasi guru. (NL, wawancara, Agustus 2009)
Dari hasil wawancara tersebut diketahui bahwa mutasi guru hanya dilakukan pada Tahun 2008. Dari data primer diketahui bahwa guru-guru tersebut dimutasikan ke sekolah SMAN LB khusus Kabupaten Jeneponto, sesuai dengan Keputusan Bupati Jeneponto Nomor 821.25-09 tanggal 15-072008 sebanyak 7 orang guru mata pelajaran dan semuanya ditempatkan di SMAN LB khusus Kabupaten Jeneponto. Dari fenomena ini dapat dicermati bahwa tujuan dilaksanakannya mutasi yaitu agar tidak terjadi ketimpangan antara sekolah-sekolah yang diunggulkan dengan sekolah yang tidak diunggulkan belum terpenuhi secara optimal. Kemudian setelah peneliti mengkonfirmasikan hal ini pada kepala sekolah tempat mengabdi sebelumnya, beliau mengatakan bahwa:

Guru-guru terbaik kami dipindahkan ke sekolah SMAN LB Khusus Kabupaten Jeneponto sehingga jumlah kekurangan guru di sekolah kami bertambah. Seharusnya setelah dimutasi, pemerintah mengangkat guru pengganti untuk mata pelajaran yang lowong (AN, wawancara Agustus, 2009).

Hasil wawancara tersebut memberikan gambaran bahwa guru mata pelajaran yang lowong karena adanya mutasi belum diisi sehingga jumlah kekurangan guru semakin bertambah. Menurut Sutarto (1995) bahwa apapun alasan terjadi lowongan dalam suatu organisasi, yang jelas ialah bahwa lowongan itu harus diisi, bahkan tidak mustahil ada lowongan yang harus diisi dengan segera, salah satu teknik pengisiannya adalah rekruitmen.

Berdasarkan fenomena ini dapat dicermati bahwa pelaksanaan mutasi sebagai upaya mengimplementasikan kebijakan penyebaran pendidik tidak serta merta menutupi jumlah kekurangan guru SMA di Kabupaten Jeneponto dan pemerataan pendidik antara satu sekolah dengan sekolah lainnya. Hal ini juga sesuai dengan tanggapan responden ketika diminta pendapatnya atau penilaiannya tentang upaya perekrutan dan mutasi guru di Kabupaten Jeneponto seperti yang telah disinggung pada Tabel 9, bahwa mereka juga sebagian besar $58,4 \%$ yang menganggap kurang serius atau tidak serius upaya mutasi guru di Kabupaten Jeneponto. 
Menanggapi masalah pemerataan guru, $\mathrm{H}$. Darwis Tanar selaku Koordinator Pengawas mengungkapkan bahwa:

Ketidakseimbangan penempatan para guru khususnya guru mata pelajaran memang sudah sangat memperihatinkan. Di tingkat SLTA Kabupaten Jeneponto masih terdapat banyak kekurangan guru mata pelajaran khususnya di sekolah-sekolah yang jauh dari kota seperti SMA 1 Bangkala Barat yang kekurangan 10 guru dan SMA 1 Batang yang kekurangan 16 Guru. Sementara disisi lain semua sekolah mengalami kelebihan guru dan yang paling signifikan kelebihannya adalah pada SMA 1 Tamalatea sebanyak 9 orang.

Kurang efektifnya proses belajar mengajar yang disebabkan karena masih banyaknya mata pelajaran yang lowong gurunya, maka agar proses belajar mengajar tetap berlangsung, disiasati dengan memberikan tanggung jawab kepada guru tertentu yang dianggap bisa meskipun berbeda dengan kompetensi dan kualifikasinya. Seharusnya agar terjadi pemerataan diadakan mutasi yang tepat, dengan menata dan mendata kembali keadaan guru disetiap sekolah, kemudian memutasikan guru dari sekolah yang surplus gurunya kepada sekolah yang kurang atau sekolah yang membutuhkan. Setelah itu barulah dilaksanakan perekrutan untuk memenuhi kebutuhan guru setiap sekolah. (wawancara, Juli 2009)

Berdasarkan wawancara tersebut, ketimpangan yang terjadi akibat penyebaran guru yang tidak merata di seluruh sekolah SMA di Kabupaten Jeneponto sehingga masih terdapat surplus guru di satu sekolah sementara sekolah lain mengalami krisis guru mata pelajaran. Hal ini dapat dilihat pada SMA 1 Binamu yang kelebihan guru mata pelajaran fisika 2 orang, sementara di sisi lain SMA 2 Binamu dan SMA 1 Batang masing-masing kekurangan 1 orang guru mata pelajaran Fisika.

Demikian pula yang terjadi di SMA 1 Tamalatea yang kelebihan guru mata pelajaran Geografi, Biologi, Bahasa Ingris, Sejarah, PPKN dan Kimia masing-masing 1 orang, sementara disisi lain SMA 2 Binamu kekurangan guru Georafi dan Kimia masing-masing 1 orang,
SMA 1 Binamu kekurangan guru mata pelajaran Biologi dan Kimia masing-masing 1 orang, dan SMA 1 Batang kekurangan guru Bahasa Ingris dan Sejarah masing-masing 1 orang.

Dari penjelasan beberapa fenomena yang disebutkan di atas, dapat disimpulkan bahwa mutasi yang dilakukan tidak berakibat pada terpenuhinya kebutuhan guru serta pemerataan penyebaran guru di seluruh sekolah SMA di Kabupaten Jeneponto. Padahal Pemerataan Penyebaran pendidik dalam hal ini guru sangat penting dilakukan untuk memacu dan meningkatkan prestasi pendidikan secara bersamaan antara sekolahsekolah yang ada di kota maupun yang berada di kecamatan. Selain itu, jika terdapat kecenderungan guru mengajarkan mata pelajaran yang berbeda dengan kompetensinya maka guru akan sulit meningkatkan kompetensi profesionalnya. (AN, wawancara Agustus 2009).

\section{KESIMPULAN DAN SARAN}

Implementasi kebijakan peningkatan kompe-tensi pendidik yang tertuang dalam Peraturan Daerah Nomor 4 Tahun 2006 tentang Rencana Pembangunan Jangka Menengah Tahun 2006-2008 yang memuat diantaranya peningkatan rasio pendidik melalui pengangkatan dan penyebaran pendidik belum dilaksanakan secara proporsional dan professional sehingga masih saja terjadi kirisis sekaligus surplus guru mata pelajaran di sekolah SMA di Kabupaten Jeneponto.

Hal ini disebabkan perekrutan yang dilakukan tidak sesuai dengan kebutuhan guru di setiap sekolah SMA di Kabupaten Jeneponto. Selain itu dari data sekunder diperoleh informasi bahwa terdapat guru yang mengajarkan dua mata pelajaran berbeda yang tidak sesuai dengan kompetensi keilmuannya. Sehingga diharapkan Agar Pemerintah Daerah Kabupaten Jeneponto dalam hal ini Dinas Pendidikan, Pemuda dan Olahraga Kabupaten Jeneponto secara komprehensif mengimplementasikan kebijakan peningkatan 
kompetensi pendidik melalui perekrutan, penempatan dan penyebaran tenaga pendidik secara proporsional dan profesional sesuai dengan kebutuhan sekolah sehingga keadaan surplus dan krisis guru yang terjadi secara simultan pada sekolah SMA di Kabupaten Jeneponto dapat diminimalkan.

\section{DAFTAR PUSTAKA}

Danim. 2002. Inovasi Pendidikan: Dalam Upaya Meningkatkan Profesionalisme Tenaga Kependidikan, 'Bandung: Pustaka Setia.

Depdikbud, 1999. Filosofi, Kebijakan dan Strategi Pendidikan Nasional Jakarta: Depdikbud.

Dunn, William N. 1981. Public Policy Analysis: An Introduction. New Jersey: Englewood Cliffs.

Islamy, Irfan M. Prinsip-Prinsip Perumusan Kebijakan Negara. Jakarta: Bumi Aksara, 1997.

Jones, Charles 0. 1996. Pengantar Kebijakan Publik. Diterjemahkan oleh Ricky
Ismanto. Jakarta: Raja Grafindo Persada.

Putra, Fadillah. 2003. Paradigma Kritis Dalam Studi Kebijakan Publik. Surabaya: Pustaka Pelajar, 2003.

Salusu, J. 2000. Pengambilan Keputusan Stratejik, (Cet. Ketiga).. Jakarta: Grasindo.

Spencer, M., Lyle and Spencer, M. Signe. 1992. Competence at Work: Models for Superrior Performance. New York USA: John Wiley \& Son, Inc.

Tangkilisan, Wim, 2008, Mutu Pendidikan Kita, (Online). (www.Koran Indonesia) Diakses 12 Desember 2009.

Tilaar, 2000. Paradigma Baru Pendidikan Nasional. Jakarta: PT. Rineka Cipta.

Udoji, Chief J.0. 1981. The African Public Srvant As a Public Policy in Africa. Addis Abeba: African Association for Public Administration and Management.

Wahab, Solichin Abdul. 1997. Analisis

Kebijaksanaan. Jakarta: Bumi Aksara. 